\title{
The Legacy of the British Administration of Hong Kong: A View from Hong Kong
}

\author{
Ming K. Chan
}

As the one and a half centuries of British colonial rule draw to a close on 30 June 1997, it is timely to review the true legacy of British administration in Hong Kong. It would be naive to resort to any simplistic blanket judgment or to issue any sweeping endorsement or condemnation on the mixed record of the British administration. It would also be dangerous to look only at the attainments in the final days of the British regime and use them to reconstruct, or even to substitute for, the full span of British rule. Even given a charitable view of this sunset era of the British regime as its finest hour in Hong Kong, a more informed and balanced assessment of its past deeds must be appreciated in the fuller context of the actual inputs and outputs of British officialdom in shaping developments in the territory and the life of Hong Kong people during the entire course of British rule.

Hong Kong today is globally recognized as a remarkable example of a liberal society with a vibrant economy where its population of more than six million enjoy their freedom and opportunity. For this, the British can indeed claim considerable credit. As portrayed by the last British Governor Christopher Patten, four of the major British contributions to Hong Kong's success - the rule of law, the civil service, economic freedom and democratization - can be a useful starting point to articulate the true British legacy from a Hong Kong perspective. ${ }^{1}$

\section{The Rule of Law}

A much celebrated British "gift" to Hong Kong has been the rule of law, which included the British-style common law legal system with an independent and impartial judiciary supposedly delivering fair and equal justice to all. To most Hong Kong people, the preservation of the legal system is of crucial importance to the "high degree of autonomy" which the Hong Kong Special Administrative Region (HKSAR) is supposed to enjoy. However, Hong Kong's present legal system has serious defects. Indeed, a good case could be made for reform of the legal system in order to meet the requirements of contemporary Hong Kong as a complex international community and to lay a more solid foundation for the future.

While much of the structure and institutions in Hong Kong's legal system are regarded as basically sound and smoothly functioning, a major flaw has been the legal language of English. Until very recently all court proceedings in both civil and criminal litigations in Hong Kong were held in English. While an official language, English is not the mother tongue

1. Christopher Patten, The 1996 Policy Address, Hong Kong: Transition (2 October 1996). This was his last policy address as Governor.

(C) The China Quarterly, 1997 
or language of everyday usage for most local people, who are Cantonese speakers. At present, residents must speak English in order to be eligible for jury service. This plays a major part in the composition of the Hong Kong jury and renders it significantly out-of-step with contemporary ideas about the role of trial by jury. Thus, those Hong Kong Chinese who appear on the List of Common Jurors are likely to be better educated, middle-class businessmen or professionals and as such are not representative of the society which they are called upon to serve. Failure to reform the jury franchise would create the risk of the jury system losing legitimacy among the public, even jeopardizing its future under a different sovereign with a Leninist-Stalinist legal system. ${ }^{2}$

A parallel concern is the late start and inadequate progress in bilingual (English and Chinese) codification. Part of the problem stems from the personnel in the legal system. The institutions of justice are still expatriate-dominated in both the Legal Department and the judiciary branch. The government's personnel localization efforts have had only limited results and required more conscientious effort in the recruitment and training of legal personnel through reform of the legal profession and education. Localization of the common law requires long-term and far-sighted reform which could strengthen the rule of law by making the entire legal system more attuned to the demographic and socio-cultural realities as well as the rising democratic and human rights consciousness of the local Chinese populace. This much-needed sinification would help to consolidate the common law legal culture and institutions for HKSAR. $^{3}$

The British legal legacy in Hong Kong also harbours dangerous historical breaches that set unhealthy precedents for the future. The thick piles of discriminatory legislation (mostly racially based, anti-Chinese law passed by an appointed legislature) and draconian, biased (antiChinese and anti-grassroots) court rulings are not good examples of decency and fairness. ${ }^{4}$

Moreover, the executive and legislative branches have a rather weak separation of power, with inadequate checks and balances. Until 1985, when indirectly elected seats were introduced into the Legislative Council (Legco), the colonial administration had been able to pass legislation through a compliant legislature constituted by appointed members, with government officials enjoying a majority until 1976. Thus one could say that the colonial regime often operated within the law, as it had always been able to change the law through the appointed legislature. The executive branch could always claim a legal basis for any action that it

2. Peter Duft, Mak Findlay, Carla Howarth and Tsang-fai Chan, Juries: A Hong Kong Perspective (Hong Kong: Hong Kong Univeristy Press, 1992), pp. 53, 57, 58. Of the 143,798 names on the 1987 List, two-thirds are Chinese and the others mainly European, Australian and North American.

3. A recent advocate for reform of the legal profession and education is Anthony Dicks, "Will the laws converge?" the Hong Kong Lecture, University of Hong Kong, 1996.

4. Peter Wesley-Smith, "Anti-Chinese legislation in Hong Kong," in Ming K. Chan (ed.), Precarious Balance: Hong Kong Between China and Britain, 1842-1992 (Armonk, NY: M. E. Sharpe, 1994). 
wished to take. And when the administration did not wish to seek the approval of Legco, it could resort to the Emergency Regulations Ordinance of 1922 which allowed imprisonment without trial and many other breaches of human rights. Yet such acts were considered perfectly legal. Because the Emergency Power Ordinance still remains on the statute books, though all the regulations had been repealed by 1985 , the serious risk remains that the HKSAR government may apply it as did the colonial government. $^{5}$

Furthermore, the colonial regime's own illegal official acts should not be forgotten. These included film censorship without proper legal authority, ${ }^{6}$ character assassination ${ }^{7}$, and extra-legal manoeuvres to undermine or obstruct the course of justice (such as London's executive interference with the Hong Kong legal process in the Chinese government aircraft case in $1950 .^{8}$ They amounted to a gross travesty of the rule of law and the pursuit of true justice.

A host of humiliating incidents, ranging from serious criminal activities by legal personnel to dubious conduct and incompetence, have marred effective legal administration, resulting in a tarnished reputation for the legal system. ${ }^{9}$ The following recent cases illustrate the perils and predicaments of the Hong Kong legal system: the Reid and Harris cases, ${ }^{10}$ the registration of Judge O'Dea, ${ }^{11}$ and the alleged interference with Justice Caird. ${ }^{12}$ There was also Chief Justice T. L. Yang's controversial 1995 opinion on the Bill of Rights' unsettling impact on the legal system and possible contravention with the Basic Law (in the context of the PRC's intention to resurrect the old version of six local ordinances before

5. The author is fully indebted to Norman Miners on this issue; see his "The use and abuse of emergency powers by the Hong Kong Government," Hong Kong Law Journal, Vol. 26 (1996), pp. 47-57.

6. Before the Hong Kong government's enactment of an ordinance on film censorship in 1986, its film censorship had been without proper legal authority; see Michael C. Davis, "Free speech in comparative perspective: the case of Hong Kong," paper presented at the 40th Annual Meeting, Association for Asian Studies, San Francisco, 25 March 1988.

7. The regime's "dirty tricks" targeted pressure groups and politicians; see Robert Adley, All Change Hong Kong (Poole, Dorset: Blandford Press, 1984).

8. James T. H. Tang, "World War to Cold War: Hong Kong's future and Anglo-Chinese interactions, 1941-55," in Chan, Precarious Balance, pp. 120-21.

9. For a recent expose on the misdeeds of senior expatriate legal officials, see Hong Kong Economic Journal, 19 September 1996, p. 15. The relatively low conviction rate in cases handled by the Legal Department, as pointed out in the Report of the Director of Audit on the Results of Value for Money Audit (October 1996), ch. 7, reflected partly the legal staff's incompetence.

10. Christopher Harris, a senior Crown Counsel, was convicted of sexual offences. Ta Kung Pao (Dagong bao), 22 February 1990. Warwick Reid, a Deputy Director of Public Prosecutions, was convicted of corruption and several lawyers were implicated. South China Morming Post, 21 June and 2 September 1990; Far Eastern Economic Review, 28 June 1990.

11. Supreme Court judge Patrick $O^{\prime}$ Dea made international news after admitting reading a book while presiding over a robbery trial. Berry F. C. Hsu, The Common Law System in Chinese Context (Armonk, NY: M. E. Sharpe, 1992), p. 64.

12. Judge Brian Caird withdrew from the Aaron Nattrass case on 3 September 1996 on medical grounds and retracted his earlier allegations of being improperly pressured. Yet the internal judicial inquiry which found no pressure had been applied was regarded as a massive "cover-up" staged by the judiciary and left a host of questions unanswered. See South China Moming Post, 24, 28 August, 6, 26 September, 15 October; Hong Kong Standard, 25 August, 4, 11, 25-27 September, 2, 13, 15, 16 October; Sing Tao Daily, 4 September 1996. 
their amendment by the 1991 Bill of Rights). ${ }^{13}$ Public criticism was also levelled at Yang's conflict of roles in his campaign to become HKSAR chief executive while still the titular head of the judiciary. ${ }^{14}$

The rule of law is definitely a foremost British legacy for Hong Kong, and is rightly popularly perceived as such. However, it is necessary to be reminded of the significant lapses and gaps in the common law legal system as it has been practised by the colonial regime. Much effort is still needed to reform and remedy its defects and inadequacies so that it can live up to its own avowed objective: "If the people of Hong Kong are to have confidence in their judicial system, the courts must be seen to be capable of dispensing justice independently, within a reasonable period of time and in a language which the vast majority of people can understand." 15

\section{Civil Service}

The backbone of British rule in Hong Kong has always been the civil service. If the British tradition of an executive-led government is to become even more emphasized in the HKSAR, then the civil service administrative bureaucracy will remain the most powerful political institution. While much has been said of Hong Kong's civil service system as a whole as highly professional, efficient, politically neutral and relatively free from serious corruption, this can only be a partially accurate reflection of recent realities.

Precisely because Hong Kong, at least until the mid-1980s' sovereignty settlement and start of democratization, was often labelled as an "administrative state" or "bureaucratic polity" practising "administrative absorption of politics," local governance and political power were monopolized by civil service administrator-bureaucrats. In this sense, the civil service system, particularly the senior echelon, dominated the process of policy formulation, decision-making, implementation and supervision. With such a concentration of functions and power in its hands, the civil service also nurtured and perpetuated its own bureaucratic culture of elitism and even arrogance at the expense of public accountability and responsiveness. This partly explains why the senior civil service echelon is still ill-adjusted to the growing pressure for open

13. The damage was not only Yang's expression of doubts about the overriding effect of the Bill of Rights. Yang apparently violated judicial independence by bowing to executive pressure and submitted a report explaining his view to Chief Secretary Anson Chan. See Berry Hsu, "Judicial development of Hong Kong on the eve of 1 July 1997," in Ming K. Chan and Gerard A. Postiglione (eds.), The Hong Kong Reader: Passage to Chinese Sovereignty (Armonk, NY: M. E. Sharpe, 1996), p. 82.

14. In late August 1996 while on long leave, Yang announced his intention to run for the HKSAR chief executive post. It was not until 5 September that he submitted his resignation as Chief Justice to the Governor to be effective on 4 November. Although Yang did not resume active duty on the bench after his announcement, he still enjoyed his perks as Chief Justice while involved in his campaign until 27 October 1996, his revised day of effective resignation. See Sing Tao Daily, 4, 7, 26 September, 29 October 1996.

15. Hong Kong Judiciary 1994-1995 (Hong Kong: Government Printers, 1996), p. 18. For a more detailed critique of the problems in the British colonial legal system, see Ming K. Chan, "The imperfect legacy: defects in the British legal system in colonial Hong Kong," University of Pennsylvania Journal of International Economic Law, Vol. 18, No. 1 (1997), pp. 133-156. 
government and public accountability as well as the new inputs from elected politicians and political parties or pressure groups in the policy process.

The 1997-dictated decolonization also accelerated civil service localization. It is ironic that this process, which is needed because of past discrimination, should now be claimed as a British achievement. The fact that civil service localization did not become a high priority until after the signing of the Sino-British Joint Declaration in 1984 raises serious doubts about the British commitment to a genuinely professional and rational approach to personnel policy and management in its own governance. Even now, the administration's localization measures are being successfully challenged in court by some expatriate civil servants under the Bill of Rights. ${ }^{16}$ Until the early 1990s, the civil service's top ranks were dominated by British officials, and even though they were few in number (about 3,000 out of a total civil service of over 150,000 in the 1980s), several serious problems were thereby revealed as shown below.

Until the $1980 \mathrm{~s}$, these expatriate officials, while small in number, were concentrated at the top and very high levels of the hierarchy and controlled the vital processes of recruitment, assignment, supervision, evaluation and promotion of their subordinates, the majority of whom were local Chinese. The top-heavy strategic concentration of expatriates with their great power, influence, control and policy-making functions distorted this supposedly Hong Kong civil service system into a very British state machinery, thus undermining Hong Kong local autonomy.

Secondly, the expatriate domination of the civil service top echelon is not only racially discriminatory but raises serious doubts about the integrity of the entire system as a genuine meritocracy in which recruitment, posting and promotion should be based solely on rational criteria of ability, skills, performance and overall effectiveness and contribution to the local community. With some well-known exceptions, most of the expatriate top officials are illiterate or only semi-literate in Chinese. While few would doubt their professionalism and devotion, their limited literacy and understanding of the Hong Kong Chinese community and of developments in China diminished their effectiveness as Hong Kong administrators and policy-makers.

Such expatriate dominance carried the assumption that local Chinese civil servants somehow, by British official standards, lacked the ability, skills and competence to reach the top. This became the pretext for the non-promotion of local civil servants. Thus deprived of the opportunity to shoulder responsibility and gain greater experience, they of course remained "lesser qualified" or "inadequately prepared" for the top appointments. Local civil servants were also not deemed to be politically trustworthy, with unquestioned loyalty to the British crown. Hence, only

16. Sing Tao Daily, 23 November 1996; South China Morning Post, 23 November 1996. The recent court rulings found seven areas of the government's localization measures unfair and discriminatory to the affected expatriate officials. The Association of Local Senior Civil Servants regards the rulings as the "perpetuation of discrimination" against local personnel "under the name of human rights." Sing Tao Daily, 2 December 1996; Hong Kong Economic Journal, 30 November 1996. 
British officials were considered loyal enough to be fit for top positions. Such logic makes a mockery of the colonial regime's claim that it has always served the true interests of Hong Kong and has always enjoyed very high autonomy from London. Even though colonial British interests in Hong Kong might at times be at variance with the British government's interests, neither should be regarded as identical with the interests of Hong Kong's Chinese majority. ${ }^{17}$

Another result of the "glass-ceiling" of exclusion from the top ranks (and more favourable terms for expatriates than locals in the other ranks) was that many qualified and gifted local Chinese were discouraged from entering or staying within the civil service, thus depriving it of a full reservoir of candidates of high calibre and great promise. This weakened the overall quality and actual range of skills, capabilities and expertise of the civil service. The delay in full-scale, whole-hearted localization also means a failure to nurture a generation of highly experienced and proven administrative leadership that will be indispensable to the HKSAR.

Because of its elitist bias, institutionalized racism and expatriate domination within its bureaucracy, the Hong Kong government headed by an unelected British Governor could hardly claim to enjoy the legitimacy of a popular mandate. It could only aim to achieve public acquiescence or at best "administrative legality" camouflaged as "functional legitimacy."18 This has induced a sense of insecurity in the colonial bureaucracy, often resulting in the officialdom's inability to acknowledge mistakes and accept valid public criticism. This has also contributed to the lack of any longer-term vision and overall developmental objectives.

A most glaring failure of the civil service system under expatriate leadership was the senior bureaucrats' lack of any sense of the role of the government in relation to the inevitable issue of 1997 sovereignty retrocession. A lack of guidelines for the political transition rendered Hong Kong civil servants ill-prepared and even confused about how to react to political issues. The situation was exacerbated by the Sino-British discord created in 1992 by Governor Patten's electoral reforms, which politicized the senior civil servants and required them to support policy unacceptable to Beijing. This trend undermined the colonial state's recent promotion of the "political neutrality" of the civil service, probably to pre-empt the public perception in order to ward off future PRC attempts to politicize the HKSAR civil service. ${ }^{19}$ The democratization efforts also

17. In the 1980s, the UK led the drive in the EEC quota on Hong Kong textile imports, while "foreign students" fees were charged to Hong Kong students in UK universities.

18. Ming K. Chan, "Labor vs Crown: aspects of society-state interactions in the Hong Kong labor movement before World War II," in Elizabeth Sinn (ed.), Between East and West: Aspect of Social and Political Development in Hong Kong (Hong Kong: Centre of Asian Studies, University of Hong Kong, 1990).

19. Civil service political neutrality is again jeopardized by Chief Secretary Anson Chan, who upon her decision not to run for the HKSAR chief executive post, issued a political statement on the criteria for the ideal chief executive. She also congratulated C. H. Tung, but not the other two nominated candidates, on his candidacy nomination. Sing Tao Daily, 5,19 November 1996, and Sing Pao Daily News, 19 November 1996, headline. All three nominated candidates for chief executive consider the senior civil servants already too politicized and the HKSAR must restore their political neutrality. Sing Tao Daily, 30 November 1996. 
added pressure on the senior bureaucrats as salespersons of government policies to a Legco with elected members. This new public role moved then Financial Secretary Macleod to acknowledge that "we have increasingly become quasi-politicians." 20

Finally, the fact that Governor MacLehose found it necessary to establish the Independent Commission Against Corruption in 1974 reflected the existence of widespread corruption among almost all ranks and branches of the civil service. Public criticism and a tarnished international image forced the government to act, but even then MacLehose was compelled to grant a general amnesty to the entire police force in the notorious police mutiny against the Commission in 1977. This is a powerful indictor of how widespread corruption had eroded public confidence in the integrity, fairness and efficiency of the civil service two decades ago. Unfortunately, corruption among civil servants has been increasing recently. The prospect of the serious epidemic of corruption in the PRC becoming part of Hong Kong's post-1997 reality is disturbing. ${ }^{21}$

Another disturbing trend for the future HKSAR polity would be a reconfiguration of Hong Kong's pre-1985 anti-democratic power coalition in which expatriate senior officialdom worked closely with British big business and Anglicized local elites. The new power equation will see local senior bureaucrats join the Beijing-endorsed local elites, such as those on the HKSAR Preparatory Committee and Selection Committee, to preserve the status quo with a conservative, pro-business and antidemocratic orientation. The civil service top echelon's tradition of administrative supremacy and colonial authoritarianism has rendered it ill-adapted to the 1985-97 era of democratization and legislative scrutiny. Perhaps, the localized officialdom should have much common ground with the new HKSAR elites to marginalize electoral politics and the implied popular legitimacy of the democratic camp. ${ }^{22}$

\section{Economic Freedom with Limited Government}

Another often trumpeted British contribution to Hong Kong's success has been its promotion of economic freedom with limited government. In the post Second World War era, colonial officials have stressed "positive non-interventionism" as their guiding light in economic policy, helping to raise Hong Kong to its world class economic hub status. ${ }^{23}$

20. Hamish Macleod, "Hong Kong: a hard-earned success," in Government Information Services, Hong Kong 1995: A Review of 1994 (Hong Kong: Government Printers, 1995), p. 20.

21. John P. Burns, "Civil service systems in transition: Hong Kong and China," in Ming K. Chan (ed.), The Challenge of Hong Kong's Reintegration with China (Hong Kong: Hong Kong University Press, 1997), pp. 31-48.

22. Anthony Cheung, "The transition of bureaucratic authority; the political role of the senior civil service in the post-1997 governance of Hong Kong," paper presented at the Conference on Hong Kong in Transition: Political Order, International Relations and Crisis Management, Hong Kong, 18 September 1996.

23. An authoritative view on "minimal government" is then Financial Secretary MacLeod's "Hong Kong: a hard-earned success." 
It has often been said that with free trade and a free port as the cornerstones of the economy, the combination of low taxation, a truly open market, the free flow of information/technology/capital, and a minimum of regulation and official red-tape has yielded considerable room for the private sector to maximize profit. In essence, Hong Kong's economic miracle seems to be the direct result of the official minimalist approach. ${ }^{24} \mathrm{~A}$ careful examination of the historical record, however, reveals an interventionalist regime whose actions did not always conform to its projected laissez-faire façade. ${ }^{25}$

While free trade remains the hallmark of Hong Kong's economy, the colonial government has continuously played a direct and crucial role as a very significant economic participant. Besides its control of valuable resources, the regime's command of the relevant legal, political and social institutions and processes also indirectly shapes economic behaviour and societal development. It could be argued that the continuous projection of the "positive non-intervention myth," despite a very different reality today, serves several purposes.

This official stance was a useful lure to the international business community. It emphasized free trade, low tax, and unlimited opportunity for free enterprise because of the absence of regulation and official interference in order to attract investments in Hong Kong. Domestically, limited government with a laissez-faire façade aimed at minimizing the colonial state's role as an active protector, provider and promoter of many community needs. This stance could help to de-escalate the rising expectations of an increasingly affluent and modern society. In turn, the public's limited claim on governmental services helped to limit expenditure, hence the continuation of low taxation and the slower growth of bureaucracy. Finally, the "minimalist" regime's limited responsibility aimed at encouraging the private sector to carry the lion's share of societal undertakings and also discouraging further influx of immigrants from China by making sure that Hong Kong was no welfare state utopia.

This was the mentality fostered by a colonial regime supposedly practising "positive non-interventionism." However, during the post-War years, three successive waves of the China Factor - the 1949 Communist revolution and the influx of immigrants from China, the 1967 Cultural Revolution-inspired leftist urban terrorism disturbances, and since the 1980s, the 1997 syndrome - all affected the colonial polity and socioeconomic order and necessitated considerable reorientation in the actual undertakings and new commitments of the British administration of Hong Kong. Thus, since the late 1960s the China Factor effects, combined with demographic growth and a greater complexity of community requirements, have forced the once uncaring and aloof colonial regime to cater more to grassroots needs. In the last three decades, the Hong Kong government's involvement in everyday life has increased steadily and now reaches into many vital areas of socio-economic development.

24. See Alvin Rabushka, Hong Kong, A Study in Economic Freedom (Chicago: University of Chicago Press for the Graduate School of Business, 1979).

25. Ming K. Chan, "Stability and prosperity in Hong Kong: the twilight of laissez-faire colonialism?" Journal of Asian Studies, Vol. XLII, No. 3 (May 1983), pp. 589-598. 
The government is the monopoly owner of scarce resources (land), and the largest landlord in Hong Kong (with over 40 per cent of the population living in public housing). It also imposes rent control on some private housing. Through its fully-owned public corporations it operates the three railways and also regulates the other major transport services and public utilities as monopoly franchises. Most of the education system is government subsidized. While much of Hong Kong's welfare and charity programmes are provided by private and voluntary organizations, their budgets are heavily subsidized by the government, which also sets basic policy and supervises the delivery of services. All public and subvented hospitals come under the jurisdiction of the Hospital Authority, which is a government appointed and funded public body. In the 1980s, the government took over the ownership and management of several insolvent local banks to prevent a general bank run. These are just a few examples of a government which is actively involved, fully engaged and often interventionist, whether by design or necessity. Taken together they should substantially modify the government's "positive non-intervention" self-characterization. The main focus here is not the merits or demerits of the interventionist or non-interventionist stance of the regime. Rather this discussion aims at clarifying the actual role of the colonial state in societal and economic development vis-à-vis the official claim to, and public perception of, the principle of laissez-faire in this articulation of the British legacy in Hong Kong.

One could argue that the myth of laissez-faire economic policy has also served the purpose of white-washing dubious, unfair government practices. Contrary to the ideal of free trade and the open market, the colonial authorities resorted to discriminatory and monopolistic measures that constituted interventionist actions. Noted examples include the mandatory use of only British motor vehicles by the franchised public bus companies until 1983, and the monopoly status granted to British university degrees and British-derived professional qualifications for academic, professional and even business purposes.

In this context, the most damaging legacy was the blatantly probusiness bias in the government's decision-making. A notable point is the special status enjoyed by British business in Hong Kong, especially the collusion between the colonial officialdom and the British economic elites, with an almost quarantined Executive and/or Legislative Council seat for the taipans of the Hong Kong Bank, and such British hongs as Swire and Jardine. This not only enabled them to enjoy special access to power, information and policy inputs, and in crisis situations (such as the 1922 Seamen's Strike) the support of the colonial state against the local Chinese grassroots, ${ }^{26}$ but it also distorted the basic orientation of the state in its larger societal responsibility. Indeed, the colonial regime has been at fault for its subservience to business interests as manifested in its unwillingness until very recently, not because of laissez-faire but from its pro-business bias, to legislate against cartels and monopolies and to

26. Chan, "Labor vs crown." 
regulate economic activities in the interests of labour, consumers and the environment. Even in the more "enlightened" post-1967 era, business interests received a disproportionally large share of representation in the Executive Council (Exco) and Legco, taking an average of 40 per cent of the seats in the two councils until the introduction of Legco direct elections in $1991 .^{27}$

While no one could deny the remarkable economic growth and rising affluence in Hong Kong during the past three decades under British rule (with GDP per capita increased from US\$686 in 1966 to US\$23,200 in $1996^{28}$ ), the pro-business, positive non-intervention heritage of the regime still left an alarming socio-economic disequilibrium on the eve of British departure. Behind the impressive GDP figures is a widening income gap between the super-rich and the grassroots, with 650,000 people reportedly living below the poverty line. ${ }^{29}$ Despite the increase in the budget's allocation for welfare, the British regime has been unable to resolve the survival crisis of the poor and needy effectively.

In other words, free trade and free enterprise with an open market for much of colonial Hong Kong history did not always mean fair trade and equal opportunity: the regime intervened to favour British and big business interests at the expense both of fair play and of a level playing field for all economic players regardless of class or race. ${ }^{30}$ The crux of the issue is not whether limited government did promote the economic freedom responsible for Hong Kong's recent prosperity. Rather, the question is when, how, with what motives and in whose interest the colonial state decided to intervene in the social and economic spheres. If the state had to intervene in its roles of public protector, promoter and provider, then it should have been the local Hong Kong majority interest that deserved consideration. Yet, in its very nature as a colonial regime with a British-dominated bureaucracy, it often confused and even blatantly substituted British for local Hong Kong interests. That such British economic giants as the Hong Kong Bank and Jardine had to relocate their corporate domicile overseas before 1997 emphasized the fact that their days of special privileges and unfair advantages would be gone forever.

In unmasking the hypocrisy of laissez-faire colonialism with all its past record of unfair and discriminatory socio-economic practices, one may also be apprehensive about the likelihood of mainland Chinese corporations and elites, not unlike the British hongs in the past, striving to claim special privileges and even monopolizing some of the HKSAR's economic sectors. This could be facilitated by the British-groomed local elites who are shifting their loyalty to Beijing, thus providing a powerful network of co-optation and political patronage as in the classical British colonial example. ${ }^{31}$

27. Hong Kong Economic Journal, 26 September 1996.

28. The 1966 figure is from MacLeod, "Hong Kong: a hard-earned success," p. 7; the 1996 figure is from Patten, The 1996 Policy Address, Hong Kong: Transition, section 36.

29. Sing Tao Daily, 18, 25 October, 4 November 1996; South China Morning Post, 18 October, 4 November 1996.

30. Recently, the Consumer Council called for the introduction of competition laws to ensure a level playing field for business; see South China Morning Post, 29 November 1996.

31. The author wishes to thank Sonny S. H. Lo for his insights on this point. 
Perhaps the myth of laissez-faire capitalism as projected by the colonial regime has appeared so real that it even prompted PRC officials to criticize the increase in Hong Kong public welfare spending as "runaway welfarism," with the Patten regime "driving recklessly toward a fatal crash." 32 This not only represents Beijing's interference in local policy-making and resource allocation, which should be in the purview of Hong Kong's autonomy; it also reflects a commonly held but erroneous perception of the Hong Kong economic miracle. In this sense, while Hong Kong's laissez-faire characterization might have been disproved in academic debates more than a decade ago, the lingering shadow of positive non-intervention still colours the realpolitik of sovereignty transition. $^{33}$

\section{Democracy}

Perhaps the most regrettable shortcomings of the British colonial presence in Hong Kong have been its inadequate efforts at democratization. The very fact that British-sponsored democratization only emerged after the 1984 Joint Declaration seemed to justify Beijing's criticism, and called into question the motives and potentially troubling consequences of the British eleventh-hour change of heart to democratize Hong Kong right on the eve of their departure. Of course, it is for the British to explain and justify why there was no commitment to democratization during the first 140 years of their administration of Hong Kong. Yet it is still useful briefly to review the many missed opportunities, deliberate non-actions and even anti-democratic manoeuvres of the colonial regime. This should serve as a needed balance to any selfcongratulatory portrayal of democratic advancement under British rule. While one might find $\mathrm{Mr}$ Patten to be the most energetic among all British Governors in his promotion of democratic reform, the list of democratic reform-minded Governors is indeed rather short-Mark Young $(1941,1946-47)$, and Edward Youde (1982-86). ${ }^{34}$

32. South China Morning Post and Sing Tao Daily, 29, 30 November 1995. Also see Far Eastern Economic Review, 9 November 1995, p. 36 on Hong Kong's inadequate welfare provisions.

33. See A. J. Youngson, Hong Kong Economic Growth and Policy (Hong Kong: Oxford University Press, 1982), ch. 4. A recent input on this issue is the policy platform by Peter K. C. Woo, one of the three nominated candidates for HKSAR chief executive, which calls for a substantial modification of the "positive non-intervention" approach. Hong Kong Economic Journal, 13 November 1996. Yet Financial Secretary Donald Tsang resorted to the Basic Law's stipulation on preserving the capitalist system to refute the front running candidate C. H. Tung's call for government assistance to local industry. See Sing Tao Daily, 4 December 1996. A scholarly study on industrialization in the context of the colonial regime's laissez-faire is Stephen Chiu, The Politics of Laissez-faire: Hong Kong's Strategy of Industrialization in Historical Perspective (Hong Kong: Hong Kong Institute of AsiaPacific Studies, The Chinese University of Hong Kong, 1994).

34. On the MacLehose and Youde eras, see James T. H. Tang and Frank Ching, "The MacLehose-Youde years: balancing the 'three-legged stool,' 1971-86," in Chan, Precarious Balance. 
Ironically, it was pressure from both the local grassroots and the revolutionary Kuomintang-Chinese Communist Party United Front in Guangzhou, as manifested in the devastating 1925-26 Guangzhou-Hong Kong General Strike-Boycott, that caused the first Chinese member to be appointed to the Exco in 1926. It was a response to the strikers' demand for the right of local Chinese directly to elect their representatives to the Legco. ${ }^{35}$ But the British patronage system to recruit local elites not only perpetuated the elite-officialdom collusion that characterized much of the undemocratic elite politics of colonial Hong Kong, but also sowed the seeds of future miscarriages of democracy.

The post-War British plans for limited democratic reform were shelved by an unsympathetic Governor Grantham and the colonial tycoon elites who, as hand-picked British appointees, were definitely not legitimate representatives of local majority interests. Using the perceived threat of the 1949 Chinese Communist victory and the 1950-53 Korean War as pretexts, the colonialist-tycoon elite axis, with the blessing of Whitehall under the Conservatives, derailed this first attempt at democratization. It could be said that those members of the local elite appointed to the Exco and Legco were more than eager to protect their own privileges and exalted positions against any widening of political participation. ${ }^{36}$

It was not any lack of far-sighted ideas and practicable proposals that underlaid the British administration's deliberate denial, deferment and derailment of democratization until the 1980 s, using as pretext circumstances outside Hong Kong, especially the China Factor. Even in the 1980 s, there was only lukewarm, half-hearted commitment to democratic reforms and electoral arrangements with a snail's pace approach through highly manipulative and illegitimate means; one notorious scandal was the Wilson administration's deliberate disregard of public opinion (which was mostly in favour of introducing directly elected Legco elements in 1988 ) in order to appease Beijing. ${ }^{37}$ After the historic first direct election of 18 members (out of a total of 60 seats) to the Legco in September 1991, Governor Wilson appointed another 18 Legco members, 16 of them with clear anti-democratic inclination (an exact equivalent to the 16 directly elected democratic camp members). ${ }^{38}$ Subsequently many of these 16 Wilson appointees, together with a few indirectly elected Legco members from the business functional constituencies, formed the Cooperative Resources Centre, which in 1992 became the conservative, pro-business Liberal Party. It was this Liberal Party bloc that almost

35. Ming K. Chan, "Hong Kong in Sino-British conflict: mass mobilization and the crisis of legitimacy, 1912-26," in Chan, Precarious Balance, pp. 48-51.

36. On the failure of the Young plan for democratic reform under Grantham, see Steve Y. S. Tsang, Democracy Shelved: Great Britain, China, and Attempts at Constitutional Reform in Hong Kong, 1945-1952 (Hong Kong: Oxford University Press, 1988).

37. Ming K. Chan, "Democracy derailed: realpolitik in the making of the Hong Kong Basic Law, 1985-90," in Ming K. Chan and David J. Clark (eds.), The Hong Kong Basic Law: Blueprint for "Stability and Prosperity" under Chinese Sovereignty? (Armonk, NY: M. E. Sharpe, 1991), pp. 9-13.

38. Frank Ching, "Toward colonial sunset: the Wilson Regime, 1987-92," in Chan, Precarious Balance. 
stopped Governor Patten's electoral reform which was passed by a single vote on 30 June 1994.

Many of these Liberal Party elites had by then already defected to the pro-Beijing anti-democratic coalition which strongly opposed the Patten reform. In the words of PRC National People's Congress member, Dorothy Y. C. Liu, these "ex-colonial old batteries" now under the new sovereign's politics of elite patronage, enthusiastically play their part in Beijing's transition power organs. ${ }^{39}$ They fully endorse Beijing's decision to disband the elected 1995 Legco and to install an appointed "provisional legislature" which has no legal or constitutional justification under the Joint Declaration and the Basic Law. In this ironic twist of role transformation from colonial "fire brigade" to PRC hatchetmen, they at least show consistency and continuity in their anti-democratic stance, bowing to the whim of an undemocratic political master. If Governor Patten were indeed sincere in his democratization push, he should deeply regret the failure of his predecessors in not laying the foundation for Hong Kong democracy with an earlier, fuller-scale and more whole-hearted promotion of democratic political culture, institutions and processes. ${ }^{40}$

If Governor Patten and Whitehall criticize the undemocratic and unrepresentative (hence illegitimate) composition of the HKSAR Preparatory and Selection Committees for being overwhelmingly filled with tycoons and their professional-circle allies, the British should not be too harsh in their condemnation of Beijing's preference for plutocracy as the future HKSAR political leadership for many of their targets of criticism were groomed and nurtured by British colonial elite politics. ${ }^{41}$ In this sense, British colonialism is a thoroughly implicated accomplice to Beijing's retardation of democracy in Hong Kong.

\section{Conclusion}

In retrospect, it may be fair to say that looking at the full spectrum of the one-and-a-half centuries of British administration of Hong Kong, it is definitely not the best, although far from the worst, record of colonial rule in the world. Even if the intended efforts and actual attainments of the British regime in its sunset era of the last decade were to be accepted as generally positive (as portrayed in Governor Patten's last policy address), that the earlier years were filled with discrimination, unaccountable or even unlawful actions, biases and favouritism cannot be denied. Nor can

39. South China Morning Post, 31 March 1997.

40. This author argued, at the end of Wilson's governorship, that his true record could only be measured by the difficulties faced by his successor; see Hong Kong Economic Journal, 1 July 1992. When Wilson deferred Legco direct election from 1988 to 1991 to meet Beijing's requirement for "convergence" with the yet to be finalized Basic Law, he could at least eliminate all appointed seats in the Urban/Regional Councils and the 19 District Boards. Wilson's failure doomed Patten's 1994/95 reform of these two tiers as Beijing has promised to reintroduce appointed seats to these councils and boards in the HKSAR.

41. A recent critique of elite politics is sociologist (and HKSAR Preparatory Committee member) Siu-kai Lau's lecture, "Political order and democratization in Hong Kong - the separation of elite and mass politics," the Hong Kong Lecture, University of Hong Kong, 1996. 
the damage inflicted on Hong Kong's people because of inaction or the lack of adequate and timely measures by the British authorities be redeemed by later remedial efforts. Of course, such a mixed record of British rule in Hong Kong is also burdened by an acute lack of popular mandate and of genuine legitimacy, inevitable in a colonial regime imposed from London. Indeed, colonialism and imperialism are in themselves, as manifested by the British and other powers' behaviour in Asia and elsewhere in the world, immoral and unjustifiable by today's standards of human rights and democracy.

The British regime in Hong Kong in its final days was still far from truly democratic, fully accountable, uncorrupted, efficient and effective in meeting the basic needs of the populace. The British-style rule of law, always regarded as the single most significant British legacy in Hong Kong, was weakened by the sullied records of its legal system personnel and by a history of legal impropriety and dubious legislation. The dark side of colonialism is also manifested glaringly in what many people still regard as the British betrayal of the long-term interests of the Hong Kong people in the 1982-84 sovereignty retrocession negotiations and in the subsequent British appeasement of PRC infringements of, and noncompliance with, the Joint Declaration, especially on democratization and the formation of the Court of Final Appeal. ${ }^{42}$

After affixing her signature to the 1984 Sino-British Joint Declaration, Prime Minister Margaret Thatcher had repeatedly emphasized the British Government's "moral responsibility" towards Hong Kong's people. However, in her "Foreword" to a recent volume on Hong Kong, Lady Thatcher only asserts that "a free economy, the rule of law, and the excellent administration ... have been Britain's most important contributions to the Territory." ${ }^{43}$ It is revealing that she does not include democracy among the British contributions to Hong Kong.

Another still unclosed chapter of unilateral British imposition of a heavy burden under the Thatcher regime is the Vietnamese boat people issue. Since the late 1970s, without the consent of the Hong Kong people, London unilaterally adopted the policy of "first port of asylum" that invited tens of thousands of Vietnamese refugees to the "free port" of Hong Kong. Besides creating problems of law and order and further pressing the very limited space of the territory for camp sites, the British did not even pay the massive expenditures for the boat people's long stay. The United Nations Refugee Commission still owes Hong Kong more than $\$ 100$ million for this purpose. ${ }^{44}$ It is doubtful whether this problem

42. See Mark Roberti, The Fall of Hong Kong: Britain's Betrayal and China's Triumph (New York: John Wiley, 1994).

43. Margaret Thatcher, "Foreword," in Sally Blyth and Ian Wotherspoon, Hong Kong Remembers (Hong Kong: Oxford University Press, 1996).

44. In his October 1996 policy address, section 17, Governor Patten gave a figure of 12,000 as the total number of Vietnamese boat people still remaining in Hong Kong. The highest figure of 68,748 was recorded in 1979, see Donald H. McMillen and Man Si-wai (eds.), The Other Hong Kong Report 1994 (Hong Kong: Chinese University Press, 1994), p. 180. The United Nations' non-payment of over $\$ 100$ million was raised in the HKSAR chief executive candidates' question-and-answer sections; see Ta Kung Pao, 30 November 1996. 
will be resolved before 1 July 1997. Is this part of the British legacy to be inherited by the HKSAR?

To appraise the legacy of British colonial rule from a proper historical perspective, perhaps one should attempt to divide the history of British administration in Hong Kong into more distinct phases, such as before the Second World War, the early post-War period, initial reforms during the 1960s and 1970s, and post-1984 reforms under the shadow of 1997. Each of these phases, though all underpinned by a fundamental will to impose and sustain colonial rule on the part of the British regime, have been shaped by more time-specific and circumstance-specific factors, especially the inevitable and increasingly powerful China Factor as well as Hong Kong's own growth and complexity. What is to be left behind in Hong Kong as part of the so-called British legacy is therefore often more accidental (in terms of historical circumstances) than institutional or ideological. For example, one cannot say that the British rule of law has throughout the past 150 years been fair to all, Europeans and Chinese. Similarly, the civil service was not really corruption-clean or efficiencyand expertise-driven until perhaps the 1980s. The repeated abortive attempts at experimentation with some degree of local democracy are illustrative of a lack of sincerity on the part of British colonial establishment, which pursued mostly an instrumental approach and was ultimately unwilling to give up real power and control. In other words, it would be necessary to place those "institutions of British legacy" both in their historical contexts and in the context of institutional evolution shaped by domestic demands and circumstantial contingencies. ${ }^{45}$

Indeed, Hong Kong has made a name in the world as a successful model of development with few natural resources other than its creative and productive people. This success story of the Hong Kong model bears a significant testimony to the contributions of the British administration, which has been on the whole adaptable in meeting many difficult challenges under fast-changing circumstances. The most recent government can take some credit for the freedom, prosperity and stability enjoyed by this cosmopolitan community of 6.3 million. But it is doubtful that the Hong Kong government of a generation ago (at the time of the 1966 Star Ferry riot and on the eve of the 1967 leftist urban terrorism $)^{46}$ even came close to meeting the standards expected of a modern and fair government, even when judged by world standards prevalent at the time. As for the full one-and-a-half-centuries' record, British colonialism in Hong Kong could hardly claim to have been genuinely enlightened and legitimate. While not negating the selective positive aspects of the British presence in Hong Kong, one must be careful not to make virtues out of necessities even if the very crucial moral question of colonialism were to be set aside. In the same light, one must not give too much credit for what supposedly is a fairly effective

45. The author is indebted to Anthony B. L. Cheung, City University of Hong Kong, for his insights on these crucial points.

46. On the mid-1960s riots, see John D. Young, "The building years: maintaining a China-Hong Kong-Britain equilibrium, 1950-71," in Chan, Precarious Balance. 
and even conscientious remedial effort by a would-be rescuer who himself was responsible for the initial problem.

If the post-1997 developments in the HKSAR turn out to be far from ideal, the burden of blame should not rest entirely on misguided policies and actions by Beijing. Rather, the inadequate foundation, unhealthy political culture, flawed legal-administrative framework and questionable bureaucratic practices inherited from the British - together with the inability of the Hong Kong people to stand firmly to defend their much cherished freedom, democracy and high degree of autonomy because of their colonial deprivation - ought to be blamed as well. As such, the true legacy of the British administration in Hong Kong must await the unfolding of HKSAR developments to demonstrate how successful the British-endowed institutions, personnel, procedures and processes as well as the values, skills and mind-set of a free economy and a liberal, pluralist society, have prepared and empowered the Hong Kong people to meet the challenge ahead. 